\title{
Red Ring Nematode, Bursaphelenchus cocophilus (Cobb) Baujard (Nematoda: Secernentea: Tylenchida: Aphelenchina: Aphelenchoidea: Bursaphelechina) formerly Rhadinaphelenchus cocophilus ${ }^{1}$
}

\section{A. S. Brammer and W. T. Crow ${ }^{2}$ \\ Introduction}

Bursaphelenchus cocophilus causes red ring disease of palms. Symptoms of red ring disease were first described on Trinidad coconut palms in 1905. Red ring disease can appear in several species of tropical palms, including date, Canary Island date and Cuban royal, but is most common in oil and coconut palms. The red ring nematode parasitizes the palm weevil Rhynchophorus palmarum L., which is attracted to fresh trunk wounds and acts as a vector for B. cocophilus to uninfected trees.

\section{Distribution}

Red ring nematode is found in areas of Central America, South America and many Caribbean islands, specifically Barbados, Belize, Brazil, Colombia, Costa Rica, Ecuador, El Salvador, French Guiana, Grenada, Guyana, Honduras, Mexico, Nicaragua, Panama, Peru, San Blas Islands, St. Vincent, Surinam, Tobago, Trinidad and Venezuela.
In some areas, mainly from Mexico to South America and in the lower Antilles, B. cocophilus is co-distributed with its primary vector, $R$. palmarum. The red ring nematode has not yet been reported from the continental U.S., Hawaii, Puerto Rico or the Virgin Islands (as of 2000). R. palmarum has been found in Central and South America and east from some of the West Indies to Cuba.

\section{Economic Importance}

In Trinidad, red ring disease kills 35 percent of young coconut trees. In nearby Tobago, one plantation lost 80 percent of its coconut trees. Over a 10-year period in Venezuela, 35 percent of oil palms died from red ring disease. In Grenada, 22.3 percent of coconut palms was found to be infected. Of those infected, 92 percent had been invaded by palm weevils. It is estimated that 72 percent of those weevils were carrying B. cocophilus (Esser and Meredith 1987).

\footnotetext{
1. This document is EENY-236, one of a series of Featured Creatures from the Entomology and Nematology Department, Florida Cooperative Extension Service, Institute of Food and Agricultural Sciences, University of Florida. Published: September 2001. This document is also available on Featured Creatures Website at http://creatures.ifas.ufl.edu. Please visit the EDIS Website at http://edis.ifas.ufl.edu. Additional information on these organisms, including many color photographs, is available at the Entomology and Nematology Department website at http://entnemdept.ifas.ufl.edu/. 2. A. S. Brammer and W. T. Crow, Entomology and Nematology Department, University of Florida, Gainesville, FL.
} 
Considering that more than eight million acres of coconut palms are grown, red ring nematodes are one of the most important pests in the tropics.

Although B. cocophilus and R. palmarum are not found in Florida, some other potential beetle vectors of the red ring nematode - Metamasius hemipterus and Rhynchophorus cruentatus - are common in Florida. If the nematode were introduced to Florida, an epidemic could potentially occur. Therefore, this nematode is of great regulatory concern.

\section{Symptoms and Effects}

Internal damage can be seen within two to three weeks after B. cocophilus enters the tissue of a healthy palm. External symptoms can take up to two months to appear.

The major internal symptom of red ring infection is the telltale red ring (Figure 1) for which the disease was named. A crosswise cut through the trunk of an infected palm one to seven feet above the soil line usually will reveal a circular, colored band approximately 3 to $5 \mathrm{~cm}$ wide, variable with the size of the tree. The surface of the cut in a healthy tree appears a solid, creamy white. The most common color of the band is bright red, although the shade can vary from light pink or cream to dark brown in infected African oil palms.

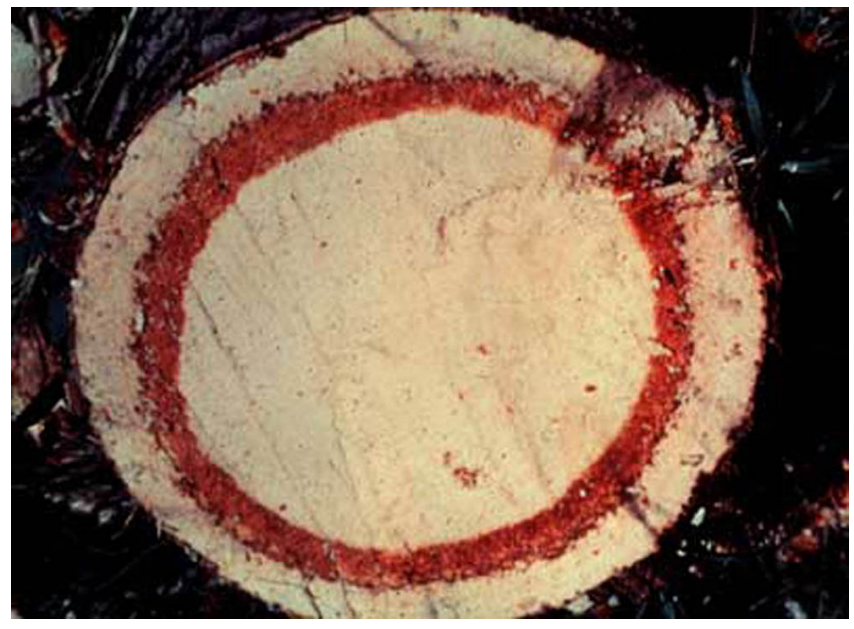

Figure 1. The telltale red ring seen here in a cross-section of a palm indicates that this particular tree is infested by red ring nematode, Bursaphelenchus cocophilus. Credits: Society of Nematologists slide collection

In external symptoms, already-established leaves become short and deformed and turn yellow-bronze, then deep reddish-brown. The color change usually begins at the tip of each leaf and starts in the older leaves before moving to the younger ones. As the leaves change color and dry up, they wilt and die.

In some African oil palms and older coconut palms, infected trees begin to produce small, deformed leaves that retain their green color and are not initially necrotic. This is a sign of little leaf disease, a chronic disease that can lead to red ring disease. New leaves often get shorter as the disease progresses, causing the central crown of the tree to resemble a funnel (Figure 2). Eventually, these new "little leaves" display varying degrees of necrosis. These trees often stop producing fruit. This symptom is not as common in coconut palm as it is in African oil palm (Chinchilla 1991, Giblin-Davis 2001).

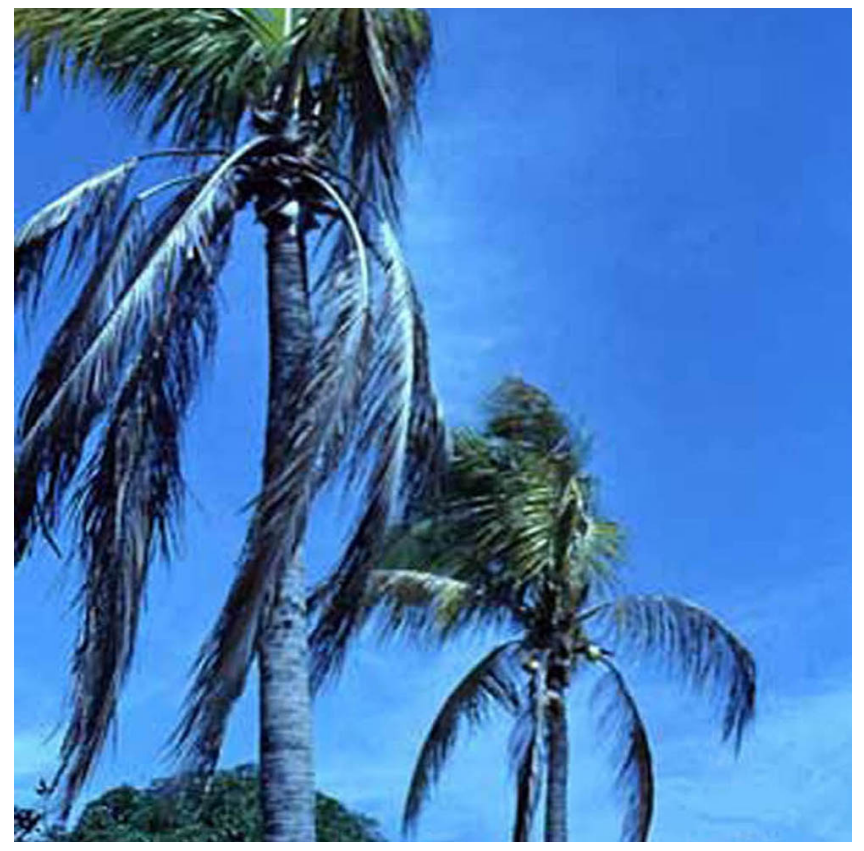

Figure 2. Smaller-than-usual and dying leaves are one of the symptoms of red ring disease, caused by the red ring nematode Bursaphelenchus cocophilus. Credits: Society of Nematologists slide collection

In coconut palms, red ring nematodes most often attack trees between three and seven years old. These young trees usually die six to eight weeks after the appearance of symptoms. Older trees can live up to 20 weeks (Esser and Meredith 1987). In some areas, infected trees can live several more years, and in some of these trees, the disease becomes chronic, manifesting itself in the continuing production of little leaves for years. Not many palms recover from 
red ring disease. The few that do recover often undergo a recurrence of the disease in later years. Trees that have been affected by red ring disease for more than three years are noticeably stunted compared with healthy trees of a similar age (Chinchilla 1991).

\section{Life Cycle and Biology}

The life cycle of $B$. cocophilus lasts nine or ten days. It is the third larval stage that is typically deposited in a palm by $R$. palmarum as it lays its own eggs there. Inside the tree, the red ring nematodes eat, grow and reproduce. When the weevil eggs hatch, immature nematodes associate with the larvae and can remain inside them as the weevils undergo metamorphosis. When the weevils mature, they leave the palm with new batches of third-stage larval nematodes ready to infest a new tree. The nematodes do not reproduce inside the weevils (Chinchilla 1991).

The red ring nematodes primarily invade the parenchymatous tissue of the palm in a band where the red ring develops. It is unknown why these nematodes stay relatively confined to this zone.

Red ring nematodes are typically slender and about $1 \mathrm{~mm}$ long. They are closely related to the pine wilt nematode B. xylophilus that causes pine wilt disease of pine trees.

\section{Dissemination and Infection}

The main vector of red ring disease is the palm weevil, $R$. palmarum (Figure 3), although vectors such as ants, spiders and other types of weevils also have been reported. The palm weevils are attracted to wounds or cuts in the trunks of the palms. Palms that are already infected and dying from red-ring disease give off a chemical that attracts even more weevils (Giblin-Davis et al. 1996). At an infected palm, a weevil ingests the red ring nematodes or picks them up on the surface of its body. Those nematodes are then left behind at the next palm, usually transmitted as the weevil lays its eggs. The nematodes also can be transmitted by tools that have been used to cut down infected trees.

On the body of a weevil or in the soil, red ring nematodes survive less than a week, but they can

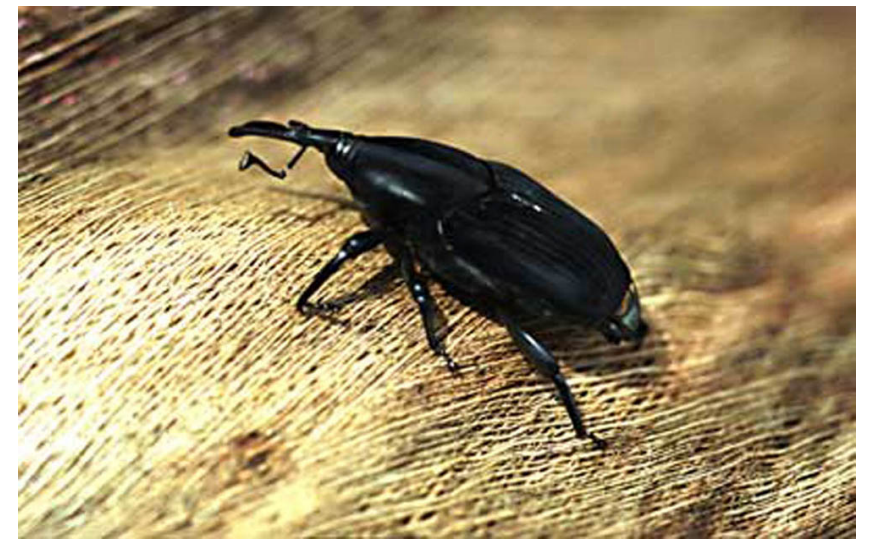

Figure 3. The palm weevil Rhynchophorus palmarum acts as the primary vector for red ring nematode, Bursaphelenchus cocophilus, which causes red ring disease in coconut and oil palms. Credits: Ulrich Zunke, University of Hamburg, Germany

survive 16 weeks in nut husks and 90 weeks in seedling tissue. The nematodes may also live for long periods within the weevil. On their own, red ring nematodes can move $5.6 \mathrm{~mm}$ an hour in soil and almost $0.25 \mathrm{~mm}$ an hour in roots (Esser and Meredith 1987).

Red ring nematodes invade both palm tissue and roots. In leaves, stem and roots, they block water pathways, reducing the palm's water absorption. The heaviest concentration of nematodes can be found within a foot of the highest part of the internal red ring that is a classic symptom of red ring disease; as many as 50,000 have been found in 10 grams of infected stem tissue (Esser 1969). In the surrounding soil, nematode concentration is generally low. They have been found as deep as $80 \mathrm{~cm}$, but most of those in the soil are $30 \mathrm{~cm}$ to $40 \mathrm{~cm}$ deep (Chinchilla 1991).

\section{Management}

Treating infested palms with nematicides is difficult because the nematicides do not easily spread throughout an infested tree and often do not penetrate the area of the trunk usually inhabited by the nematodes (Chinchilla 1991).

Controlling the vector $R$. palmarum can help reduce red ring nematode infestation. Incidence of the disease fell from 10 percent to 1 percent in Mexico with palm weevil control (University of California, Davis, Department of Nematology). Insecticides can reduce palm weevil infestations. 
The most useful and most important method for management for red ring nematode is the early removal and destruction of red-ring infested palms. This aggressive phytosanitation is the best chance to halt the spread of red ring disease to other nearby trees. Infested palms should be sprayed with an insecticide and then destroyed as soon as possible once the presence of red ring nematodes has been confirmed. Sometimes weevil larvae will remain in the tissue of palms that are killed with herbicide. These trees should be cut into sections and treated with insecticide or burned (Giblin-Davis 2001).

\section{Selected References}

Chinchilla, C. M. (1991). The red ring little leaf syndrome in oil palm and coconut palm. ASD Oil Palm Papers No. 1, 1-17. http://www.asd-cr.com/ASD-Pub/Bol01/b01c1.htm (2 January 2002).

Esser, R.P. 1969. Rhadinaphelenchus cocophilus a potential foreign threat to Florida palms. Nematology Circular No. 9. Florida Department of Agriculture and Consumer Services, Division of Plant Industry, Gainesville.

Esser, R.P. and J.A. Meredith. 1987. Red ring nematode. Nematology Circular No. 141, Florida Department of Agriculture and Consumer Services, Division of Plant Industry, Gainesville.

Giblin-Davis, R.M. 2001. "Box 5.2, Red-ring disease." Howard, F.W., D. Moore, R.M. Giblin-Davis and R.G. Abad. Insects on Palms. CAB International, Oxon, UK. Pp. 276-277.

Giblin-Davis, R.M. et al. 1996. "Chemical and Behavioral Ecology of Palm Weevils (Curculionidae: Rhychophorinae)." Florida Entomologist 79: 153-167.

Giblin-Davis, R.M. 1990. The red ring nematode and its vectors. Nematology Circular No. 181. Florida Department of Agriculture and Consumer Services, Division of Plant Industry, Gainesville.

Griffith, R. and P.K. Koshy. 1990. Nematode parasites of coconut and other palms. M. Luc, R.A. Sikora and J. Bridges eds. Plant parasitic nematodes in subtropical and tropical agriculture. C.A.B. International, Oxon, UK. Pp. 363-386.

Rhadinaphelenchus cocophilus. University of California, Davis, Department of Nematology. http://ucdnema.ucdavis.edu/imagemap/nemmap/ ent $156 \mathrm{html} /$ nemas/rhadinaphelenchuscocophilus (2 January 2002). 